\title{
Risk Management Of Integration Challenges: A Case Study Of Informal Contractors Of Emerging Markets
}

Albert Tchey Agbenyegah, Durban University of Technology, South Africa Kelehile Joseph Motlhale, Tokologo Local Municipality, South Africa

\begin{abstract}
The construction industry across emerging countries are exposed to high risk volumes and uncertainties. The industry requires efficient management systems not only to render the industry sustainable but to enable the industry to become viable. This phenomenon is common occurrence in rural areas across most emerging countries which are in dire need of infrastructure repairs and building employee skills. This study identifies integration challenges as one of the high risk factors (HRFs) of the construction industry. In addition, practical suggestions were stated based on empirical findings. The nature of risks as revealed by the survey represents series of challenges that confronts informal contractors during the integration processes. Data was collected through semi-structured interviews and focus group discussions (FGDs). A total of 134 informal contractors were approached for empirical data. Being qualitative and exploratory study, the interview processes and FGDs were in two sections; four informal contractors took part in face-to-face interviews. One hundred and thirty $(N=130)$ informal contractors consisting of thirteen groups of 10 members each group participated in FGDs. Responses from interviews revealed multitudes of empirical outcomes which pointed to the complex nature of integration challenges that impede on the processes of integration. Drawing on the findings, practical recommendations were made ranging from tailored-made education and training initiatives and adequate funding models to reduce some of the integration challenges.
\end{abstract}

Keywords: Risk Management; Informal Economy; Informal Contractors; Emerging Markets

\section{INTRODUCTION}

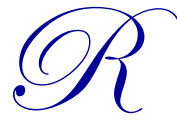

apid rural population growth without equal job opportunities has become one of the worrying factors for policy makers across the economic landscape world-wide. Informal economy of emerging countries, are faced with various forms of risks including acute shortages of basic infrastructure and lack of skills and training in environments that are besieged with challenges. Given the nature of risks within the informal economy, risk management (RM) becomes a significant concept in various entities including the construction industry. Thus, several entities cannot do without applying due processes in order to increase efficiency in performance levels. According to Tadayon, Jaafar and Nasri (2012), the construction industry is exposed to risks that impact negatively on successful implementations. Further scientific discussions on RM indicates the complex nature of risks and the challenges within the construction industry (Potts, 2008; Winch, 2002; Sanvido, Grobler, Parfitt, Guvenis \& Coyle, 1992). The construction industry in rural areas is seen as the only reservoir for job creation and the best solutions to the complex social issues (Chikweche \& Fletcher, 2014). Against the present background of high unemployment, contractors in informal economy perceived the formal economy as the only solutions to mounting problems joblessness and better access to economic opportunities. Furthermore, the formal economy is seen to be well organized due to better working environment where construction skills can be put on competitive offer for better values in contrast to situations in informal economy. The present global competitiveness of industries including the construction sector in formal and informal economy have forced several industry stakeholders to better plan to create job opportunities to meet set industry objectives. According to the Business Monitor International (2013), the construction industry continued to be challenged due to skill shortages, and lack of market infrastructure. In order to overcome some of these challenges, it is therefore crucial that informal contractors who are defined in this study as individual who offers their construction skills in informal economy try to integrate as part of the formal economy. Successful 
integration into the formal economy is perceived as the only means through which informal contractors can take advantage of available facilities that are enjoyed by peers in the formal economy. Hence, the assessment of informal integration challenges is of utmost significance.

This study discusses the integration challenges as another risk factor that confronts informal contractors in three rural local municipalities in the Free State Province of South Africa. In this study therefore, "risk" means the integration challenges as identified. The study seeks to provide solutions using RM approaches (Figure 1) to the following key question; what are the integration challenges of informal contractors? The next section presents a synopsis of the construction industry.

\section{LITERATURE REVIEW}

\subsection{Synopsis of South African Construction Industry}

The construction industry of South Africa is largely fragmented and highly dependent on economic cycles besides the present political climate. Given these situations, the construction industry is further marred by growing business failures (Enshassi, Al-Hallaq and Mohammed, 2006). The researchers further add that due to the existing climate within which the construction industry operates, the industry is perceived to be highly responsive to changing economic shifts. These conditions usher into the formal and informal economy, large scale challenges of contracting activities thus the call by informal contractors for integration.

In South Africa, much recognition for the construction industry became a reality during the 2010 Fifa World Cup tournament which brought significant job opportunities to the industry. Yet, the construction industry suffered from series of challenges including chronic lack of skillful employees in the face of high demands in the construction sector (Makhene \& Thwala, 2009). Besides, it was revealed in 2010 that employee in the construction industry have decreased significantly to 71000 (StatsSA, 2010). Further literature indicates that out of 71000 , only $46 \%$ were semiskilled in contrast to $29 \%$ which represents a very low and unskilled individuals (StasSA, 2010). A study by Rust and Koen (2011) affirm that the construction industry suffered more decline of about $3 \%$ in 2012 due to challenges of improper planning and severe lack of coordination.

The construction industry is known for its complex nature since most of its workforce are diverse.

The sector is famous for high level of level of subcontracting activities, insecure unemployment opportunities that is marred by poor working climate, approximately $50 \%$ of employees are temporary (Van Hugsteen \& Chege. 2001; Wells, 2000). According to CIDB (2004) study, the construction industry is riddled with mounting challenges such as procurement irregularities, growing corrupt practices, sub-standard construction, lack of adequate information, nepotism and unskilled labour volumes. Further scientific works indicated that $70 \%$ of the building contracts and roughly $30 \%$ of civil engineering tasks are sub-contracted (CIDB, 2013). Wong and Thomas (2010) add that it is extremely difficult to offer employment opportunities to skilled employees. The general inability of the construction industry to offer more jobs is due to the fact that as high as $70 \%$ of the entire industry's workforce only $28 \%$ are skilled and fit to be employed to work in the sector.

\section{THEORETICAL FRAMEWORK}

In discussing informal economy and its challenges known in this study as risk factors, one theory stands out to provide guidance. The dualist theory is used to provide the necessary frame in this regard. For decades, this outstanding theory is developed to provide insights into understanding different concepts including informal economy. From the dualist perspectives, informal economy is unjustifiably marginalized. Thus, it is difficult to associate any form of its activities to formal economy or to a large extent to the values of the modern capital systems (Chen, 2009). Much can be deduced from this argument. For instance, the arguments that informal economy serves as "safety nets" or "buffer zones" during difficult times means a lot since there is largely high level of unskilled pool of labour that are unable to seek job opportunities in the formal economy. The theory add that informal economy suffer limitations of socio-economic developments. According to Chakanya (2008), informal economy is known for hardships in providing adequate livelihoods for households. The next section describes the nature of RM in rural settings. 


\subsection{Risk Management in Rural Context}

Effective utilization of RM approaches is broadly confirmed by most experts in the field of management (Gajewska and Ropel, 2011). Numerous processes are used in RM. One of the processes as mentioned in extant literature entails the identifications of risk. This study have identified integrations challenges as the form of risk through empirical views expressed by participants. Figure 1 on the next page depicts an overview of how the identified challenges can be managed in specific rural contexts. The level of challenges (risks) within the informal construction industry still remains very complex and interrelated to specific environment. Thus, an all-inclusive approaches to RM requires holistic combination of risk elements as well as various interrelated approaches and initiatives. Occasional review of integration challenges and management programs are required to reduce its effect on rural construction industry because of quick exposures and for various reasons. Besides, it is critical to conduct proper audit in RM programs on continuous bases.

Figure 1. Outline of RM approaches

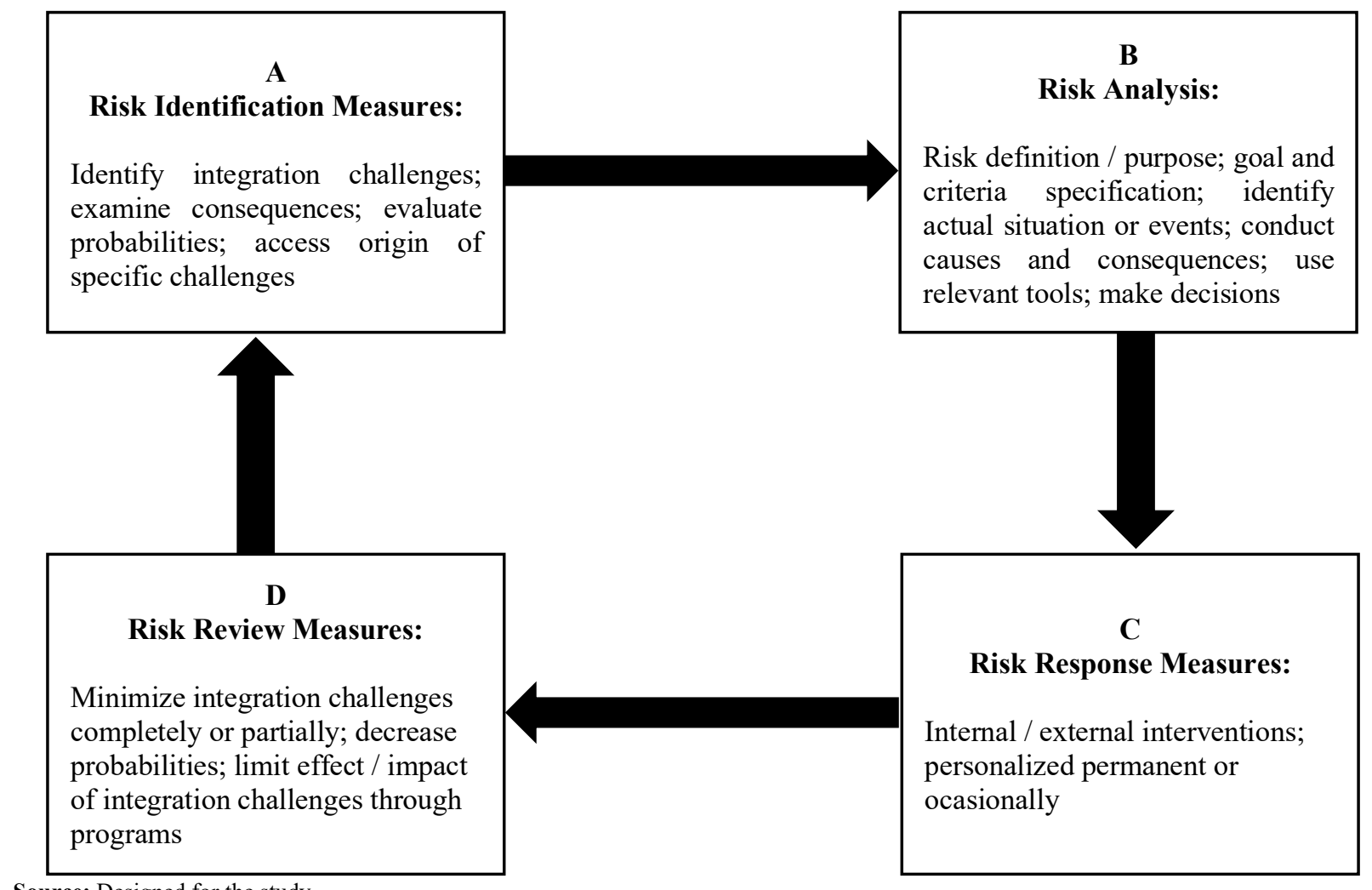

Source: Designed for the study

\subsection{Contextualizing Integration Challenges}

Different challenges which poses in the form of risks persist during the integration process. These risks emanate from rural settings and constitutes the risk of lack of infrastructure; lack of information and inadequate training on integration processes. For the purpose of this study, a narrow definition is used to define integration as a process of uniting two diverse economies that varies in economic activities but with a common working formula aim at utilizing available resources. Based on this definition, the study discussed two streams of integration and linked the two economies to different socio-economic conditions. As envisaged, in a team activities, two extreme situations exist with drawbacks which are highly risky. Chingono and Nakana (2008) agreed that defining the concept of integration lacks agreement in literature on various fronts yet it depends on specific situations. In this study integration is hampered by multitude of constraints and limitations that confronts informal contractors as prescribed by literature. 
These limitations create barriers between the formal and informal economic activities; hence poses severe integration impediments especially to informal contractors who are determine to be part of the larger formal economy. Challenges such as lack of information, corrupt practices, unskilled labour, poor infrastructure and inability of informal contractors to understand policy framework.

Aside these challenges, lack of policy cohesion at national level for requisite guidance towards informal economic activities are a major cause of concern (Munyaradzi, 2011). Another study by Palmer (2008) alluded that apprenticeship training is another limitation to informal economic activities as such without training, informal contractors are most likely to display severe poor tradesman ship. Informal contractors are unable to successfully integrate as part of the formal economy. Some of the outstanding challenges that impede informal economy include lack of government protection through policy frameworks and the nature of infrastructure decay (Chen, 2004).

\section{METHODOLOGY}

\subsection{Research Design}

This empirical study was conducted in three local municipalities of the Free State Province of South Africa. Figure 1 below indicates these local municipalities as Boshof, Dealesville and Hertzoville. The researcher used qualitative and exploratory tools of semi-structured interviews besides FGDs for empirical data. The period for gathering the empirical data spanned for more than two weeks in 2017 across three local municipalities in the Tokologo Local Municipality (TLM) of the Free State Province of South Africa.

\subsection{Target Population and Sampling}

This study sourced the target population from all the informal contractors who resides and at the time of the study work as informal contractor as defined in the three rural municipalities of Boshof, Dealesville and Hertzogville. In total 300 informal contractors were earmarked to participate in the study.

Figure 2. Map of the research setting

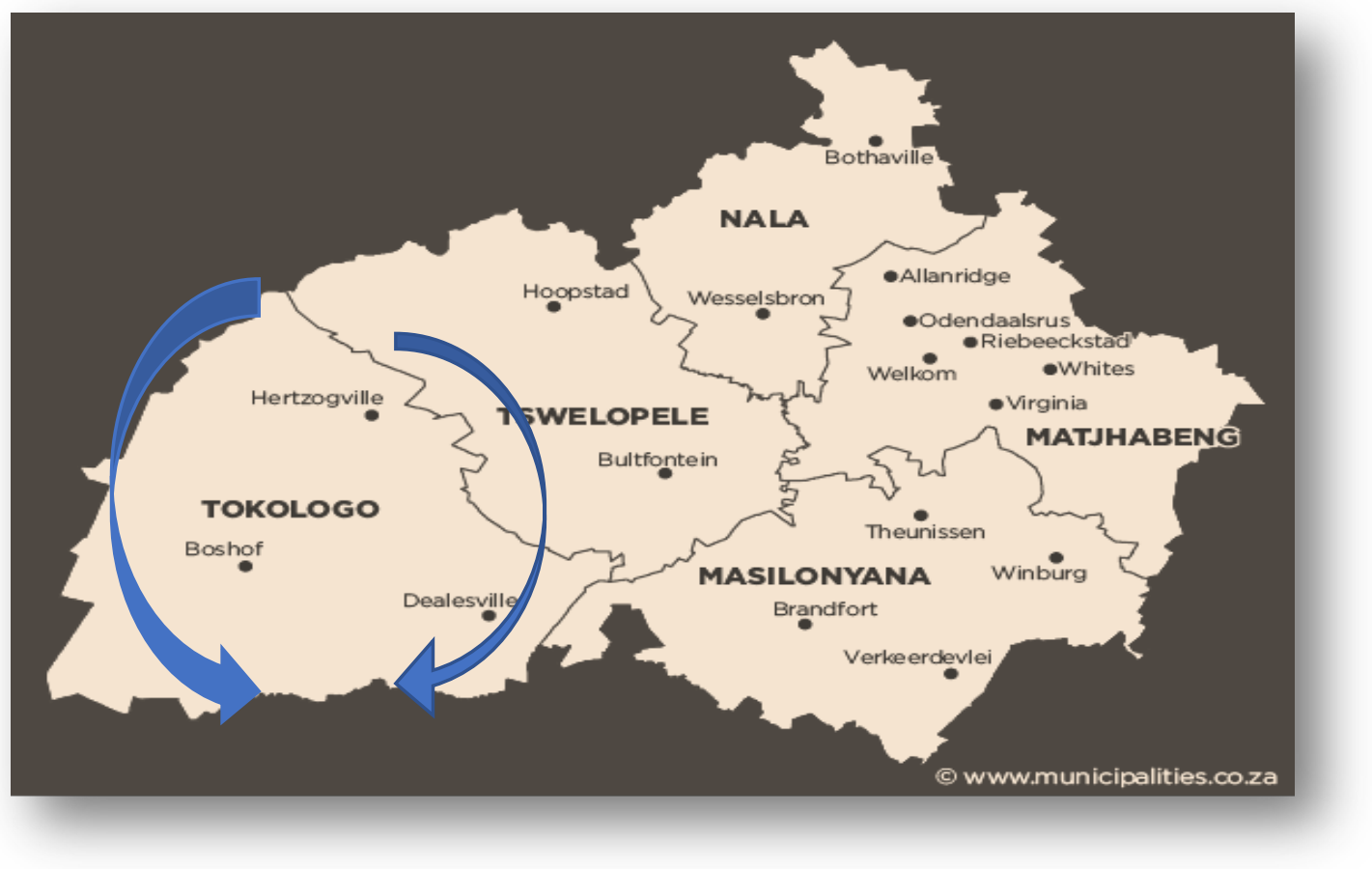




\subsection{Sampling}

Informal contractors who participated in the study were recruited through the strategic snowball sampling method (Patton, 2002). The participants took part in semi-structured interviews and FGDs. During the planning of the semistructured interviews and FGDs sessions, the researchers sought wide representations from informal contractors in order to gain broader perspectives on the integration challenges and the scope of other contradicting issues including challenges. In designing the interviews for FGDs, 13 groups of 10 informal contractors in each group from a total population of 130 selected contractors were organized to participate in the interview processes. These groups were labelled in the study as FGDs 1 to FGDs 13. The next group consisted of only four informal contractors who also participated in the semi-structured interviews and were labelled as R1 to R4. This four groups of individuals were interviewed in their respective homes at different times as arranged and agreed. Informal contractors as used in this study consists of community members who resides in the study areas of Boshof, Dealesville and Hertzogville.

\subsection{Research Instrument}

The interview guide was used in the study. The questions that were earmarked for the study were structured in an open-ended format. The researchers paid particular attention to ensure that all the questions were aligned to the objectives. The themes that formed part of the questionnaires were demographic profiles of informal contractors, legal and environmental compliance, and general business information, infrastructure within the construction industry, manpower, skills, education and training. The semi-structured interviews and FGDs sessions elicited questions mainly based on the integration challenges of informal contractors across the study areas. The questions were open and closeended format to allow for more probing and elaboration on specific questions for clarity (Maziriri \& Madinga, 2015). More specifically, the participants were questioned to share more insights regarding (a) infrastructure challenges (b) shortages of skills (c) education and training (d) issues regarding regulatory framework (e) funding (f) general knowledge and $(\mathrm{g})$ access to information on business environment.

\subsection{Data Collection}

Two main data collection processes were used in gathering data for this study. Data for the study was qualitatively gathered through processes of FGDs and individual. The entire process was in the format of semi-structures interviews. In both cases, the interviews processes lasted for the duration between 20 to 30 minutes during the individual and the FGDs. The interview guide was piloted to ensure that all the questions conform to the required standards and themes for the purposes of clarity. Only few informal contractors were involved in the piloting process. Additional assistance was seek from fellow researchers for their inputs. Due to the nature of the study areas, the researchers took field notes during the interview sessions. Other electronic means such the Olympus digital recorder was applied to capture individual responses during the entire interview processes. This was after the researchers explained and seek permission from the participants and sought their trust. Besides, the researchers sought from the participants an atmosphere of trust to promote non-disclosure of information. Credibility and trustworthiness as data collected was possible through continuous scrutnization of research instrument (Strenbert \& Carpenter, 2011). In addition, the trustworthiness of the entire process was assured through the rich experiences of the participants (informal contractors) (Brink, Van der Walt \& Van Rensburg, 2012).

The immediate environment where the interview processes took place was well thought-out to ensure high participations and for more inputs (Botma, Greeff, Mulaudzi \& Wright, 2010). The researchers pasted distinctive signs on the doors of the community hall to inform the public of ongoing interview processes. Large tables and chairs were arranged with adequate spaces to ensure that participants' responses in various groups can be recorded and to allow the researchers good contact with each participants in their respective groups (Polit \& Beck, 2012). During the interview processes, recordings is captured on separate files and labelled with specific codes to enhance confidentiality and respondents' anonymity.

FGDs of 10 groups participated in a 20 to 30 minutes interview processes. The process lasted for two weeks in the community hall. During the FGDs, participants were arranged in a group of 10 each. Data collection throughout the FGDs was only stopped as the researchers discovered that saturation point is reached and no fresh concepts or themes were raised by participants (Mason, 2010). In total 13 groups were involved in the discussions of specifics topics 
throughout the entire process to enable participants provide insightful group information (Cronin, 2008). The researchers were mindful that the discussions bears similarities to what transpired during the individual processes. During the FGDs, the researchers allowed the group members to discuss each interview questions for sometimes till a common agreement is reached.

\subsection{Data Analysis}

This section focuses on minimizing data that is intended for meaningful findings about the research process (Cooper $\&$ Schindler, 2011). Data analysis focuses on the field notes taken and transcripts from the recording during the semistructured interviews and FGDs. These were the main areas where the researchers sought the key data for analysis. All the sections of the study were based on thematic framework in analyzing the data. The Thematic framework is justified since it can be used to assess uncertain words, various statements or ideas that were expressed by participants (Namey, Guest, Thairu \& Johnson, 2008).

Several themes based on the integration challenges such as infrastructure, education and training, volumes of information on unskilled labour were derived from literature including limitations to funding projects. Themes were developed in line with the integration challenges using the thematic framework during the analysis stages. Initially codes were formulated and transferred into the Microsoft Excel Spreadsheet loaded and analysed by means of a qualitative data. However, during the process, some difficulties were identified. One such difficulties was long hours spent on identifying the relevant themes from the integration challenges base on extant literature. In addition, much care was taken to read and transcribe every data for further evaluation (Creswell, 2003).

The ATLAS.TI Software was used to code, organize and match all the various codes and for data transcription. This exercise was preceded by revising and refinement of every relevant data into groups that emerged from the integration challenges. During the process, the researchers tried to avoid ambiguities. Data presentation was strictly based on the ultimate themes as interpreted and presented. During the course of data interpretations, meaningful quotations by participants formed part of the final study outcomes. The next section of this study outlined the interpretations of the study results in line with the analysis.

\section{RESULTS AND DISCUSSION}

The empirical outcomes provided were in line with the objectives of this study. This study seeks to identify the integration challenges of informal contractors in Boshof, Dealesville and Hertzogville. Drawing form several literature and empirical data thus far, some relevant themes have surfaced during the semi-structured interviews and FGDs. The integration challenges best be conceptualized in four different themes namely: Legal and environmental compliance, general business information, infrastructure within the construction industry and manpower, skills, education and training. Notwithstanding the demographic variables of informal contractors, the above themes allowed to in depth insights through sufficient expressions by participants in their various groups during the semi-structured interviews and FGDs on specific themes. Below is the demographic profile of informal contractors who took part in the study.

\subsection{Demographic Profile of Informal Contractors}

A total of 134 informal contractors took part in this qualitative study. The majority of the informal contractors were black males. This study used youthful informal contractors of $38.8 \%$ of $20-29$ years old. Another group $26.1 \%$ between the aged groups 30-39 years; followed by 19.4\% aged group between $40-49$ years were the least. However, half of the participants were under the age 50 years. This implies that the age characteristics was a fair representative of a rural setting where unemployment is rife. Large number of participants had qualifications below matric qualifications. In terms of trade and vocational skills, only $7.5 \%$ and $2.2 \%$ participants have qualified; while $33.6 \%$ majority were matriculants. Degree and diploma holders were $9.7 \%$ and $21.6 \%$ respectively. This implies that majority of participants received some form of education; thus can without difficulties work in formal economy. Most $48.1 \%$ and $36.8 \%$ of participants had between 4 and 5 to 10 years of working experience in the construction sector. A sizeable number of participants $38.6 \%$ were self-employed as informal contractors. 


\subsection{Legal and Environmental Compliance}

Informal contractors who participated in both semi-structured and FGDs indicated numerous integration challenges on both the legal and environmental compliance. In general, individual interviews and FGDs interactions gave account of insufficient education and training that made the majority of participants not to either understand or received much knowledge on the legal environment in order to comply in the construction industry. This tendency was however, described by R1 and R2 as "lack of education poses much limitations on operations; in fact, it makes us not to run our businesses as required." Another participant, R3 further emphasized "we are not able to find it easy in seeking work-related opportunities in the formal economy." Further discussions regarding business ownership also revealed that there was lack of directions through the established framework in the informal construction industries. The result further demonstrates that education is critical to the survival of the informal construction industries. The result correlates with previous survey which touched on the importance of education and training in the construction industries (CIDB, 2007).

Judging from the words of participant R3 it became clear that to own a business in informal economy and to comply is not easy due to its complex environment. In his words, "It is impossible to own a business in this environment; we live from hand to mouth just to feed our families, ownership is not the key here." This finding bears similarities to a study by UNIDO (2009) which states that the informal environment is very complex and uncertain; thus very difficult for contractors to operate. Participant R3 added "it is difficult to own businesses here; you pay for everything and stick by the rules while you make small profits"; "yaa" "the issue of land in this environment still remains another challenge." A study by Van der Merwe (1997) states that ownership of private lands in informal economy is very difficult in comparison to public land ownership. Given all these barriers, private business ownership is not easy. Given these answers, it implies that informal contractors were unable to think of owning businesses, instead rely on others from their counterparts in the formal economy. Additional responses from FGDs 4 and 7 have shown that there is severe lack of information regarding the legal and general business environment. Participants FGDs 7 added "no one inform, train or educate us on issues of the environment; we are left to fight our own, we don't know if the situation is the same in the formal economy. " This finding further echo the general severe challenges of education and training and lack of knowledge in the construction industries (CIDB, 2007).

Regarding the questions on business registration and policy compliance, individual groups R1 to R4 and FGDs stated that their businesses were not registered; that they hardly comply with existing business legislations. In this regard, the participants overwhelmingly reiterated that they operate unregistered businesses. According to participant R1 "this is not my fault; the reasons are that I did not understand these legislations on business registration." "Most of us reside in rural villages we don't pay taxes our roads are bad, simply there are no roads, no medicines in our clinics." This finding resonates with precious study by Du Toit and Neves (2014) who revealed that informal contractors are not protected by any form of policy. The issue of education formed center stage of further discussions. The general remarks were associated with lack of education and knowledge. FGDs 11 and 12 reiterated "we are not educated, no support and above all we lack the exact knowledge in this regard." The overarching finding resonates with previous survey which revealed that lack of information and knowledge impact negatively on informal economic activities (Van Wyk, 2003).

\subsection{General Business Information}

During the semi-structured interviews, the FGDs sessions, participants were asked to provide insights on their business operations. On the general working conditions, responses from participants were mixed. According to R1 and R2 all is not well in the informal economy. From their responses, the working conditions was good but the environment lack proper grading and levels. Further responses from R1 and R2 revealed that the business environment was not on their sides. In their words "am not happy but nowhere to go and search for daily bread for my family." On questions regarding payments for services and transparency, participants revealed that there is no transparency in payments and for services. FGDs 1 and 2 were of the view that informal economy lack transparency in terms of services rendered and payments thereof. Participants R1 and R4 that there was no level of transparency in terms of payment for services; "we do not participate in pricing of goods and services nor negotiate." "We want to determine the price offers for contracts and subcontracts." The result that emerged from recent study indicates that the informal environment continue to experience high volumes of exploitation (Becker, 2004). 
On questions regarding business funding, all participants stated that funding of contracts and even subcontracts was not easily accepted by banks. Both individuals and FGDs mentioned that the banks are unwilling and lack trust as businesses of informal contractors are either registered not the members are not unionized. One of the groups; FGDs 5 mentioned that "the banks always insists on security for funds, in the informal economy we do not even have title deeds for our lands -it is difficult to provide security.” According to Van der Walt (1997), acquisition of private land was not easy. Furthermore, a study by Tomlinson (2010) found that banks are only prepared to charge very high interest rates across the informal economy. Other responses from individuals stressed the use of own family capital for business operations. Further responses from FGDs 6 and 8 stated "I use my own funds, from family members to operate my own business, no bank support or even government"; "we are unable to build proper housing or other projects due to lack of money too much material costs." These findings are in line with similar studies which states that the construction industry lack efficient developers due to exorbitant increases in prices and lack of price stability (Van Wyk, 2003; Cockayne, 2011; CIDB, 2007).

\subsection{Infrastructure within the Construction Industry}

During the interviews both individual and group participants were asked about the status of market information in informal economy. Respondents provided varying answers. It was evident that marketing information was none existent to participants. These challenges were once again linked to lack of education and training. Respondent R4 at the semi-structured interviews stated "informal market is limited, no funds as most people are unemployed." Similar sentiment is shared by FGDs 6 "it will be better and more beneficial with opportunities if we work in the formal economy with abundance of information." The group added "that environment is full of better training and knowledge."

Drawing from these challenges, the participants further stated "there is lack of infrastructure; no roads, telephone and no designated land for business operations and to establish own business." According to groups FGDs 1 and 9 "there are slow training processes in informal economy, lack of adequate government support and inability to acquire sites to establish business." These findings are in line with Van der Merwe (1997) survey which claimed that it was extremely difficult to access private lands for business operations. Boshoff (2010) add that in South Africa, there is much supply of public lands in contrast to private lands. Responding to similar infrastructure challenges, the majority of participants add that the present marketing facilities were below the required standards. They cited an example of telephone facilities in the study areas are broken, not in working conditions. According to FGDs 7 "it is not easy for us to inform the public about the services we offer in order to get contracts"; "always I ask my boss for assistance to use telephone," "as for energy supplies, it is dead and like non-existent always in the dark." From the recent survey by Eberhard (2010), it emerged that in rural areas energy supplies is limited. According to Mbande (2010), the construction industry can perform better provided there is ongoing infrastructure repairs. The government need to spend more funds in repairing existing rural infrastructure (CIDB, 2007).

\subsection{Manpower, Skills, Education and Training}

Participants, especially those who took part in the semi-structured interviews shared their negative impressions regarding lack of manpower and skills in informal economy. Respondents, R2 and R3 stated "it is difficult to recruit from formal economy; more money is paid for higher education of qualified individuals." They continued "I am unable to raise large sums of money for highly trained someone from formal economy." In agreement to high salary payment to qualified employees, majority of respondents agreed that it is better to access manpower and skills from the local areas (the informal economy). In contrast, FGDs 4 responded "although is better to work with more qualified employees, it will be more productive in the formal economy."

Several participants stated that regarding skills in informal economy, most of them were not trained to work as contractors; in their words, the general sentiments was that the majority are trained either on the job or semi-skilled. Responding to the same issue, FGDs 12 and FGDs 13 stated "it is wrong to employ efficient and well-trained people while personally one was not." The general response by individuals R1 to R4 and the entire FGDs showed that informal contractors are unskilled; hence they are not willing to engage educated people. Also, because they are unable to offer competitive salaries. Further remarks to the issues indicated that participants earned less money thus they are not willing to employ for higher payments in return. This was deduced form the responses "I don't earn much to pay 
high salaries to anyone form the cities." "I am not educated enough; no training for the past years I earn very little for my family." This finding concurs with recent study by Van Wyk (2003) who states that most contractors are disadvantaged due to poor level of education in the industry. Milford (2010) adds that due to inadequate education and serious capacity problems.

\section{CONCLUSION AND RECOMMENDATIONS}

The main essence of this study was to investigate the integration challenges of informal contractors. Through qualitative data, a sizeable number of informal contractors stated in their responses different forms of challenges ranging from funding difficulties, inadequate education and training, lack of information and poor infrastructure among others. The study further confirms that there are challenges of lack of adequate support and funding, skills shortages among the contractors, sub-standard of education and training and lack of infrastructure. These challenges were revealed as some of the impediments during the integration processes. Given the depth of these challenges, the study contributes immensely to existing literature on informal economy. In addition, the study provide the necessary platform for further discussions in terms of integrating the informal and the formal economic activities. Integrating the two economic activities could enhance rural economic development across the rural populace of South Africa. Besides, successful integration process will assist in reducing rural unemployment, reduce rural poverty rates and minimize income disparities as informal contractors would access urban infrastructure facilities in favour of their contracting businesses.

\subsection{Recommendations for Informal Contractors}

Local municipal authorities (LMAs) should be cautious in dealing with one of the main challenges "tender processes." Given the level of education among informal contractors, tender processes continue to be flawed due to lack of knowledge and requisite information to informal contractors. To curb this challenge, LMA should be mindful during the tender processes to ensure that RM techniques (Figure 1) are applied. Access through education programs to information is very vital in this regard because without information the contractors cannot create the rightful information.

Based on empirical outcomes, the following recommendations were made. Informal contractors' responses appear to be focused on their honest desire to be part of the formal economy. This desire is motivated by the availability of resources and better facilities in the formal economy. From their responses working in informal economy seems to be stressful and frustrating. Individual and group responses point equally to the fact that there are constraints that are believed to have negative influence on their daily operations. Drawing from the study outcomes thus far, it came to light that most informal contractors are experiencing funding difficulties; thus, they are still not at a stage to navigate these challenges. The local municipal authorities need to intervene on their behalf in finding suitable rural funding model (RFM) to offer financial support.

It is further recommended that tailored-made education and training programs be instituted in rural communities. Through the training programs, informal contractors would be able to learn new skills similar to their peers in the formal economy in order to access critical information relevant to their operations. Other information on industry policy framework, union matters, information on business registration as well as tax issues. Further revelation from the study have shown that the challenges of infrastructure is of high concern. In this regard it is recommended that the local authorities embark on overhaul of existing infrastructure. Besides, the researchers are of the opinion that infrastructure policy framework (IPF) be established at local authorities.

\subsection{Practical Approaches to Reducing Integration Challenges}

It emerged from the study that integration challenges impede various ways. Hence, the processes to integrate as part of the formal sector becomes impossible. Some of the challenges as realized form the verbal responses of participants attested to the complexities of informal economy. Table 1 below recommends practical overview of the applicable programs to reduce the integration challenges. 
Based on the Table 1 below, the study recommends that more education and training programs are required as the best solutions to reduce the integration challenges. The study further recommends that for both high, minor and low challenges education and training programs must be applied. These solutions can only be fruitful provided integration challenges are viewed closely to determine the level of frequencies.

Table 1. Association of integration challenges and RM solutions

\begin{tabular}{c|c|c|c|c|c|}
\hline $\begin{array}{c}\text { Nature Of } \\
\text { Integration } \\
\text { Challenges }\end{array}$ & Frequencies & $\begin{array}{c}\text { Severity Of } \\
\text { Integration } \\
\text { Challenges }\end{array}$ & $\begin{array}{c}\text { Likelihood Of } \\
\text { Integration } \\
\text { Challenges }\end{array}$ & $\begin{array}{c}\text { Effect Of } \\
\text { Integration } \\
\text { Challenges }\end{array}$ & Possible Solutions \\
\hline Very minor & Very high & Very low & Very high & $\begin{array}{c}\text { Minimal } / \\
\text { Negligence }\end{array}$ & Education \\
\hline Minor & High & Low & For short period & Insignificant & Education \\
\hline Medium & Low & Medium & $\begin{array}{c}\text { Reasonable: } 5 \text { to } \\
10 \text { years }\end{array}$ & Serious & $\begin{array}{c}\text { Education and } \\
\text { training }\end{array}$ \\
\hline Large & Very rare & High & Very high & Continuity & $\begin{array}{c}\text { Personalized } \\
\text { training }\end{array}$ \\
\hline
\end{tabular}

Source: Designed for the study

\section{LIMITATIONS AND FUTURE STUDY}

Even in a carefully planned research climate, the researcher is faced with the potentials of limitations on a large scale (Fouche, 2006). Thus, every scientific study is without limitations. Thus, the researchers observed two vital limitations during this study. Initially, this study focused only on two rural local municipalities. In view of this, its outcomes cannot be generalized to include other rural communities of South Africa. In future, a comprehensive study should be conducted to include the rural settings in South Africa across every province to allow for comparison of the outcomes. Another limitation was the fact that this study is based on a small sample size. This outcome further calls for larger sample size in the future for a more representative outcomes which can easily be generalized. Lastly, there is the need to conduct mixed methods (qualitative and quantitative) research in the future to get deeper insights of the phenomenon.

\section{AUTHOR BIOGRAPHY}

Albert Tchey Agbenyegah holds a PhD in Business Administration from North West University Potchefstroom, South Africa. Currently an employee of the Durban University of Technology (DUT) Riverside Campus, Dr Agbenyegah research interest includes rural entrepreneurial activities and rural small businesses, technology education and strategic management.

Kelehile Joseph Motlhale is currently an employee of the Tokologo Local Municipality (TLM) of the Free State Province of South Africa. Mr. Motlhale holds a BTech degree. His research interest includes the integration of informal to the formal economy. Other research interest risk elements within the construction industry of the informal economy.

\section{REFERENCES}

Becker, K. (2004). The Informal Economy: Fact Finding Study. SIDA, Stockholm.

Boshoff, S. (2010). The Cape Town 2030 initiative: A contested vision for the future. In Counter-Currents: Experiments in Sustainability in the Cape Town Region. Cape Town: Jacana Media (Pty) Ltd and African Centre for Cities, 70-79.

Botma, Y., Greeff, M., Mulaudzi, F.M. \& Wright, S.C.D. (2010). Research in Health Sciences. Cape Town: Clyson Printers.

Brink, H., Van der Walt \& Van Rensburg, G. (2012). Fundamentals of Research Methodology for Health Care Professionals. Cape Town: Juta.

Business Monitor International. (2013). South Africa infrastructure Q1. [Online]. Available from: http://www.businessmonitor.com [Accessed: 5 February 2013].

Chakanya. (2008). Zimbabwe Country Report presented at ILO Trade Union Training on Research and Rural Youth Unemployment 19 May-6 June 2002, Turin, Italy. 
Chen, M. (2004). Rethinking the Informal Economy: Linkages with the Formal Economy and the Formal Regulatory Environment, paper presented to Unlocking Human Potential: Linking the Informal and Formal Sectors, EGDI and UNU-WIDER Conference, Helsinki, (17-18 September).

Chen, M. (2009). 'Rethinking the Informal Economy,' in http://www.un.org/.../wp46_2007.pdf, Aug. 2004.

Chikweche, T. \& Fletcher, R. (2014). Rise of the middle of the pyramid in Africa: theoretical and practical realities for understanding middle class consumer purchase decision making. Journal of Consume Marketing, 31(27-38).

Chingono, M. \& Nakana, S. (2008). The challenges of Regional Integration in Southern Africa. African Journal of Political Science and International Relations, 3(10): 396-408.

Cockayne, R. (2011). Business Report-Construction Costs Threaten Industry. Available: http://www.iol.co.za/business/businessnews/construction-costs-threaten-industry-1.1036062. Assessed: $5^{\text {th }}$ April 2018.

Cooper, D.R. \& Schindler, P.S. (2011). Business Research Methods. Boston: Irwin/ McGraw Hill.

CIDB. (2004). South African Construction Industry: Status Report-2004. Pretoria: CIDB.

CIDB. (2007). The national infrastructure maintenance strategy in support of ASGISA and government growth objectives. Pretoria, South Africa: CIDB.

CIDB. (2013). Sub-contracting in the South African construction industry: Opportunities for development. Pretoria: CIDB. Creswell, J.W. (2003). Research Design Qualitative, Quantitative and Mixed Methods Approaches. USA, Sage Publications. Cronin, A. (2008). Focus groups. In N. Gilbert (Ed.), Researching social life, third edition (pp. 226-244). London: Sage.

Du Toit, A. \& Neves, D. (2014). The government of poverty and the arts of survival: mobile and recombinant strategies at the margins of the South African economy. Journal of Peasant Studies, 41(5): 833-853.

Eberhard, A. (2010). Africa' Power Crisis and Power Shortages in South Africa: Management Programme in Infrastructure Reform and Regulation. Available from: www.gsb.gsb.uct.ac.za/mir. Accessed: 4 May 2017.

Enshassi, A., Al-Hallaq, K. \& Mohamed, S. (2006). Causes of contractor's Business Failure in Developing Countries: The Case of Palestine. Journal of Construction in Developing Countries, 11(2), 1-14.

Fouché, C.B. (2006). "Writing the research proposal.” In: de Vos, A.S., Strydom, H., Fouché, C.B. \& Delport, C.S.L. (eds) (2006). Research at grass roots: For the social sciences and human services professions. Third edition. Pretoria: Van Schaik.

Gajewska, E. \& Ropel, M. (2011). Risk Management Practices in a Construction Project - a case study, Göteborg, Sweden: Chalmers University of Technology

Makhene, D. \& Thwala, W.D. (2009). Skilled labour shortages in construction contractors: A literature review. In: Proceedings of the CIDB 6th Post Graduate Conference, Johannesburg, 6-8 September, pp. 128-136.

Mason, M. (2010). Sample size and saturation in $\mathrm{PhD}$ studies using qualitative interviews. Forum: Qualitative Social Research, 11(3). Retrieved from

file://C:/documents\%20and\%20settings/owner/my\%20documents/Pat/NCU/Dissertation\%20proposal/mason\%20sat uration\%20article.htm

Maziriri, E.T. \& Madinga, N.W. (2015). The Effect of buyer's remorse on consumer's repeat-purchase intention: Experiences of Generation Y apparel student consumers within the Vaal Triangle. International Journal of Research in Business Studies and Management, 29(5): 24-31.

Mbande, C. (2010). Overcoming construction constraints through infrastructure deliver. Proceedings: The Association of Schools of Construction of Southern Africa (ASOCSA), Fifth Built Environment Conference. Durban, South Africa. 18-20 July.

Milford, R. (2010). Public capacity payment and procurement issues should be a challenge to the operation of contractor's in South Africa. Paper presented at the Fifth Built Environment Conference of the Association of Schools of Construction of Southern Africa. Durban, South Africa, 18-20 July.

Munyaradzi, F. (2011). The informal economy in South Africa. Nedbank Small Business Services. (Online). Available from: http//simplybiz.co.za/informal-economy-South Africa. Accessed: 15 Oct 2017.

Namey, E., Guest, G., Thairu, L. \& Johnson, L. (2008). “Data Reduction Techniques for Large Qualitative Data Sets,” In: Handbook for Team-Based Qualitative Research, Rowman Altamira.

Palmer, R. (2008). Skills and productivity in the informal economy employment sector. Working Paper No. 5. Online. Available from: http://www.ilo.org/publns. Date accessed: 16/11/2017.

Patton, M. Q. (2002). Qualitative research and evaluation methods. 3rd Sage Publications; Thousand Oaks, CA: 2002.

Polit, D.F. \& Beck, C.T. (2012). Nursing Research: generating and assessing evidence for nursing practice. Philadelphia: Wolters Kluwer/Lippincott, Williams \& Wilkins.

Potts, K. (2008). Construction Cost Management - Learning from Case studies, Taylor and Francis Group.

Rust, F.C, \& Koen, R. (2011). Positioning Technology development in the South African Construction Industry- a technology foresight study. Journal of the South African Institution of Civil Engineering, 53(1):2-8, Paper 759.

Sanvido, V., Grobler, F., Parfitt, K., Guvenis, M. \& Coyle, M. (1992). Critical Success Factors for Construction Projects. Journal of Construction Engineering and Management, 118, (1): 94-111

South Africa (DHET). (2010a). Declaration signed at National Skills Summit. Pretoria: Department of Higher Education. Statistics, South Africa (StatsSA). (2010). Quarterly Labour Force Survey, first Quarter Statistics South Africa. Pretoria: Statistics South Africa. Http://www.Stats SA.gov.za. Date of access: 15 Oct. 2017.

Copyright by author(s); $\underline{\text { CC-BY }}$ 
Streubert, H.J. \& Carpenter, D.R. (2011). Qualitative Research in Nursing Advancing the humanistic imperative. Philadelphia: Lippincott, Williams and Wilkins.

Tadayon, M., Jaafar, M. \& Nasri, E. (2012). “An Assessment of Risk Identification in Large Construction Projects in Iran" Journal of Construction in Developing Countries, Supp. 1, (57):69.

Tomlinson, M.R. (2010). Ensuring mortgage repayment in South Africa. Housing Finance International. Available from: http://www.housingfinance.org.pdf. Accessed 21 June 2017.

UNCHS (Habitat) (1996). An Urbanizing World: Global Report on Human Settlements 1996. Oxford: Oxford University Press.

Van der Merwe, J.H. (1997). GIS-aided land evaluation and decision-making for regulating urban expression: A South Africa case study. Geo Journal, 43(2): 135-151.

Van der Walt, A.J. (1997). The constitutional property clause. Juta \& Company Cape Town

Van Huysteen, L. \& Chege, N. (2001). International Labour Organisation Country Case Study of Construction, South Africa. Pretoria: Division of Building and Construction Technology. CSIR.

Van Wyk, L. (2003). A Review of the South African Construction Industry Part 1: Economic. Regulatory and Public Sector Capacity Influences on the construction Industry, Pretoria, South Africa: CSIR Boutek. Available at: http://www.csir.co.za/akani (Assessed on 15th April 2018).

Wells, J. (2000). The role of the informal sector of the construction industry in Developing Countries. Best Practices Project, CIB Task Group 29 on Developing Countries,

Winch, G. (2002). Managing construction projects, an information processing approach. Oxford: Blackwell Publishing.

Wong, J. \& Thomas N. (2010). Company Failure in the Construction Industry. A Critical Review and Future Agenda. Facing the Challenges and Building Capacity. Sydney: Fig. Congress. 